\title{
The Study of Nadine Gordimer in China
}

\author{
Cencen Lai \\ School of Foreign Languages, Soochow University, Suzhou, 215006, Jiangsu Province, China
}

Received February 6, 2021; Revised March 13, 2021; Accepted April 9, 2021

\section{Cite This Paper in the following Citation Styles}

(a): [1] Cencen Lai , "The Study of Nadine Gordimer in China," Linguistics and Literature Studies, Vol. 9, No. 2, pp. 57 62, 2021. DOI: 10.13189/lss.2021.090202.

(b): Cencen Lai (2021). The Study of Nadine Gordimer in China. Linguistics and Literature Studies, 9(2), 57 - 62. DOI: 10.13189/ls.2021.090202.

Copyright $\odot 2021$ by authors, all rights reserved. Authors agree that this article remains permanently open access under the terms of the Creative Commons Attribution License 4.0 International License

\begin{abstract}
Nadine Gordimer is one of the most remarkable contemporary English writers in South-Africa. Most of her writing dealt with moral and racial issues, particularly during apartheid. She was the first South-African writer who won the Nobel Prize in Literature for her magnificent epic writing in 1991. Since the 1960 s, academic studies on Gordimer in Western or African countries have sprung up, and a complete research system has been formed, including monographs, interviews, as well as a large number of high-quality academic paper. In China, the studies on Gordimer began at the end of the 1980s, which is late. Chinese research has gradually developed from single to diverse perspectives in the past 3 decades. This paper aims to provide an overview of academic studies on Nadine Gordimer in China chronologically, clarifying the development trend as well as offering a reference for further studies. To enhance the studies on Gordimer, the Chinese research fields need to be extended, and the depth of research can be deepened. At the same time, Chinese scholars should break the research stereotype and undertake interdisciplinary studies to improve the research system. Actively constructing the critical discourse with Chinese characteristics is also of great significance.
\end{abstract}

Keywords Nadine Gordimer, Chinese Research Status, Review, Future Study

\section{Introduction}

As the recipient of the 1991 Nobel Prize in Literature, Nadine Gordimer was the first South-African writer to win the honor for her "intense immediacy about the extremely complicated personal and social relationships". Gordimer made her name as a master of short stories. Compact and dense, her short stories convey the complexity of social events. Her novels are also close-textured and pregnant with implications, which enjoy a high reputation in the world literature. With classical style, The New York Times called her novels "as original and as beautifully written as" literary works by Virginia Woolf. Gordimer published 15 novels, 23 collections of short stories, as well as a large number of essays and other contributions in her lifetime, most of which dealt with moral and racial issues, especially about apartheid. Since 1960s, the research on Gordimer has sprung up in African and Western countries. Scholars have adopted multi-perspective and interdisciplinary approaches to make critical analysis of almost every work of Gordimer. A complete research system has been formed, including monographs, interviews, and large quantities of high-quality academic papers.

Studies on Nadine Gordimer in China began at the end of the 1980s, which is late. Novels and short stories of Gordimer have been translated into Chinese, providing chances for Chinese readers to further understand Gordimer and her works. By the end of January 2021, nearly 150 academic papers (including journal paper and dissertations) about Gordimer have been published in China, but unfortunately, no monograph. Although research on Gordimer has become more popular, "successive research on her was not achieved in China due to the common fault in oriental literature research" [1]. There are still limitations of Chinese studies on Gordimer. Consequently, this paper intends to make a review of Chinese research status of Nadine Gordimer in the past 3 decades, clarify research characteristics and development 
trend, so that a reference can be offered for further studies.

\section{Review of Chinese Research Status of Nadine Gordimer}

In the past 30 years, studies on Nadine Gordimer in China have been more popular and made progress. Nearly 150 academic paper concerning Gordimer have been published in China by the end of January 2021, including about 110 journal paper, 1 doctoral dissertation and 38 master dissertation. Unfortunately, there is still no published monograph. The research can be divided into 3 stages: the first stage (1987-2000); the middle stage (2001-2010) and the recent stage (2011-present).

\subsection{The First Stage (1987-2000)}

Chinese scholars have only published about 30 journal paper at the first stage of the research, most of which are translations or introductory articles. Studies on Gordimer in China stated with 2 articles written by Zou Hailun and Dong Dingshan in 1987. Zou introduced the plot of $A$ Sport of Nature, and Dong [2] praised Gordimer's excellent writing technique, saying that it is really not easy for Gordimer to "speak up for the oppressed as a white". After Gordimer won the Nobel Prize in Literature in 1991, Chinese readers and scholars became more familiar with Gordimer, and the number of academic paper begin to soar.

The published papers at the first stage serve as a recommendation and introduction of Nadine Gordimer in China. Starting from Gordimer's family background and growing environment, scholars put her writing in the context of South Africa's politics, history and culture, then comprehensively summarized the content and theme of her works. The "resistance consciousness" of the characters under the cruel policy in South Africa is prominent, which makes the readers directly feel the chaos and crisis of the Third World countries [3]. Gordimer's unique writing has also been widely praised by the public, because she "truly reflects the reality in life with the art in novels" [4]. Scholars made thematic criticism about Gordimer's novels. Zhang Zhongzai [5] analyzed the boundary of the fiction and non-fiction in $A$ Sport of Nature, pointing out that Gordimer can "use the real events in history to logically make the fiction in the novel more reasonable". Ren Bing et al. [6] summarized the theme of My Son's Story as "destruction". The violence existed not only between "the white and the black", but also in the white groups, even in the black groups.

The academic paper mentioned above have enabled Chinese readers and scholars have a deep understanding of Gordimer and her works, which has laid a solid foundation for the follow-up research. However, most of the researches at this stage serve as the "reading guide" [7] or "the introduction to Gordimer as a recipient of the Nobel Prize" [1], still lacking is in-depth criticism of the text.

\subsection{The Middle Stage (2001-2010)}

Studies on Gordimer in China had gradually developed at this stage. Scholars chose Gordimer as the research subject of their master or doctoral dissertation, which was a dramatic leap. Research methodologies of post-colonial / feminist criticism, narratology, and cultural criticism are commonly used. In addition, scholars began to make comparative research during this period.

\subsubsection{Post-colonial / Feminist Criticism}

Setting apartheid as the background, Gordimer focuses on the hegemony of the government due to the special colonial history and political environment of South Africa. "Major concerns in her work include racism, the crisis of Liberal values, the nature of the historical consciousness, and sexual politics" [8]. Post-colonial criticism has always been a common methodology to criticize Gordimer's works. Influenced by previous foreign studies, Chinese scholars revealed the survival dilemma and identity loss of South African people during apartheid from the perspective of "the other", "the identity" or "diaspora". Hu Zhongqing [9] examined "the inter-construction of the 'other' image between the white and the black" in My Son's Story to point out the "ambivalence" of black people towards the white, that is to say, "resentment and envy". $\mathrm{Lu}$ Qingmei [10] analyzed Gordimer's "deconstruction of colonial binary oppositions and reconstructions of social realities", which contributes to the development of multi-culturalism. Zhu Qilin [11] discussed the "different immigration identities of contemporary South Africans" in the context of global immigration, aiming at the theme of "diaspora" in The Pickup. Both the upper and lower classes are faced with the dilemma of "how to acquire identity within cultural hybridity".

At the same time, the feminist perspective in Gordimer's works has been taken into account under the post-colonial context. Although Gordimer had said in interviews that she is not a feminist, she admitted that any writing in which a woman is the protagonist can be interpreted from feminist perspective. Gordimer had created various kinds of female characters in her novels. They can be "at once elite and powerless, at once subversive and exploitative" [12], which can correspond to feminist images. Zhou Leshi [13] argued that Gordimer highlighted "what do women really demand" through "the interaction between racial identity and sexual identity" in My Son's Story. Shen Yanyan [14] and Fei Juan explored Rosa's coming-of-age process in Burgher's Daughter respectively, showing women's "self-consciousness and 
national destiny" under the complex historical background of South Africa.

\subsubsection{Narratology}

Gordimer has been well known for her unique narrative techniques. She frequently uses stream of consciousness and shifts the narrative perspectives. Time and space can also easily cross in her novels. This narration "recalls the author's processing of the past in the present while envisioning a future" [15]. As a result, scholars have drawn much attention from Gordimer's narrative strategy. In terms of My Son's Story, Ruan Hang [16] pointed out that Gordimer leaves "aesthetic blank" for readers from the aspects of "the changes of narrative perspectives", "narrative ambiguity" and "the montage", which keeps the balance between fiction and reality; Wang Tao [17] combined "personal narrative" with "national metaphor" to analyze "the double narrative strategy". Wang Mei [18, 19] not only emphasized on "free association, free direct and indirect speech" in None to Accompany Me, but also listed "dialogues in the third person narratives" of Burger's Daughter. The dialogues between the third person narrator and the characters and the reader "overturns and fragments the grand narrative of South Africa".

\subsubsection{Cultural Criticism}

Shen Yanyan has published a series of academic paper concerning cultural and political research on Gordimer. Shen [20] called "the mainstream discourse in South Africa and words from Rosa's parents" in Burger's Daughter as "Geronto-Discourse", a "cultural pathology" which influences Rosa and Gordimer similarly. Meanwhile, she identified "Ephebism" as a discourse that can decode "cultural pathology". She analyzed how "Geronto-Discourse" controlled the growth of Rosa, and how Rosa subverted the structure of "cultural pathology" with "Ephebism". When making comments on July's People, Shen [21] revealed "the subversion of political rights, real rights and cultural rights in the sick society", and looked forward to the future social culture through Gordimer's utopian vision. Moreover, Shen [22] examined on Gordimer's writing techniques such as metaphor and irony in Get A Life, to talk about "social issues" after apartheid and their "cultural implication". These papers uncover the rich cultural connotation and historical significance beyond the novels, providing a new perspective for studies on Gordimer in China.

\subsubsection{Comparative Research}

Since academic studies on Gordimer started overseas, scholars undertook comparative research between Gordimer and Doris Lessing, J.M. Coetzee, Bessie Head, Toni Morrison, etc. In China, comparative research has also emerged at this stage. Wang Xufeng [23] compared Gordimer with J.M. Coetzee and V.S. Naipaul in his doctoral dissertation, which was the first and the only doctoral dissertation about Gordimer in China. Wang identified Gordimer, Coetzee and Naipaul as representatives of "radicalism", "liberalism" and "conservatism" respectively. By reconstructing post-colonial theory, Wang compared "different attitudes of three writers on decolonization". Li Meiqin [24] compared "the existential dilemma of living in the 'others' land"" in Gordimer and Toni Morrison's novels. "While in different in personal perspectives, they show similarities in historical responsibilities". Shen Yanyan [25] discussed white boys' "pursuit of humanity in the confusion" and different life choices in Gordimer's Burger's Daughter and Coetzee's Youth. Comparative research is liminal in China.

\subsection{The Recent Stage (2011-present)}

Since 2011, Chinese scholars have published more than 80 academic papers about Gordimer. Classical research methodologies of post-colonial / feminist criticism, narratology are still popular, but most of the research results are predictable. To transcend the limits of conventional research, Lu Qingmei [26] exposed "possible complicity with the dominant colonial discourse". To avoid falling into the "trap of colonial discourse", the criticism of Gordimer should not "simply invert the binary opposition of black and white", or "take race as the standard of classification in literary". During the research, scholars should have a dialogue with the "cultural and historical memory" in the literature, to make progress on the basis of the existing researches. Since then, scholars have been generating new perspectives such as spatial criticism, eco-criticism and philosophy research.

\subsubsection{Spatial Criticism}

The spatial criticism of Gordimer focuses on works during the period of regime change or post-apartheid. As Li Meiqin et al. [27] stated that, in July's People, the "interregnum" made the white cannot exist in the "geographical and psychological space" which was originally reserved for them. "Space compression" and loss of privilege lead to "the dislocation of culture and power", so that the Western civilization had been deconstructed. The indigenous community became a "liminal space", within which people from different races, classes, genders and cultures conflicted with each other. When white children walked into "home" space of indigenous community, they successfully changed their roles "from dominator to integration messenger", so that different cultures finally crossed barriers. In post-apartheid works, "the geographic space, value space and power space of Afrikaners" [28] are overturned completely. Scholars began to reveal the "multiple spatial crises" in Gordimer's novels [29], such as the invasion of physical space and the identity dilemma of psychological 
space in None to Accompany Me. In The Pickup, "human geographic space" such as streets and cafes, and "natural geographic space" such as grassland and desert, cross each other, showing the "spiritual dilemma" in the context of globalization [30].

\subsubsection{Eco-Criticism}

Gordimer has exposed current environmental situation, such as ecological deterioration and environmental injustice in lots of works, expressing obvious ecological thoughts. Therefore, scholars have interpreted novels with the help of eco-criticism. Pang Hao'nong [31] considered July's People to be "a typical pan-ecosystem novel". "The pan-ecological imbalance and crisis existing during the period of Apartheid in South Africa" is deeply disclosed "from the perspectives of nature, culture and race". To achieve a harmonious co-existence, "the reconstruction of ecological state of ethnic groups" is essential. Other scholars pointed out that The Pickup fully embodies Gordimer's ecological female thought and ecological aesthetic consciousness. The novel is not only against "gender discrimination and nature discrimination" [32], but also advocates "constructing harmonious relationship between nature", to "get rid of the feeling of homeless", to achieve "the balance of spiritual ecological" [33]. In terms of Get A Life, Yang Li [34] demonstrated "natural ecological crisis, social ecological crisis and spiritual ecological crisis" to analyze Gordimer's "ecological stance". Jiang Meng [35] also interpreted the "crisis and salvation" of the ecological environment in the novel, and expounds the "fate of characters and environment".

\subsubsection{Philosophy Research}

With the deepening of research, Chinese scholars began to criticize Gordimer's works with philosophical theories. $\mathrm{Hu}$ Zhongqing et al. [36] believed that from the perspective of Marxism, Gordimer's later works have always been running through the theme of "alienation". The alienation of the relationship between man and himself, man and others, man and society has become a common social issue in South Africa after apartheid, which is "the most inherent issue". Liu Jie [37] also revealed the "alienated Orientalism" in Gordimer's later texts, that is, Westerns "acknowledge the existence of the East and regard it as utopian". This "warm control" is actually "stronger in dominance" than the original colonial hegemony, and the relationship between East and West is "still in a state of dislocation". What's more, scholars also examined the ethical thoughts in Gordimer's novels with ethical theory. Hu Zhongqing et al. [38] analyzed the ethical relationships between man and himself, man and others, man and nature. These three ethical relations are "interrelated and interdependent", which constitute the ethical philosophy in the novel. Xu Tian [39] explored "the reasons for the narrative ethics" of Gordimer's novels from the aspects of "ethics of story" and "ethics of narrating". Gordimer aims to enable people "obtain the real freedom and social justice" through her "ethical core" of "orientation of altruism". In addition, $\mathrm{Hu}$ Zhongqing [40] studied the biblical archetype image in Gordimer's novels. Gordimer used mythological archetypes such as "Garden of Eden" and "Cain killing Abel" to "metaphorize the major social issues in South Africa", which contains profound philosophical thinking.

\subsection{Conclusion}

In general, studies on Nadine Gordimer in China has become more popular nowadays, and achieved considerable results. During the past 3 decades, Chinese research has gradually developed from single to diverse perspectives. However, compared with other Nobel Prize writers like Coetzee, Morrison and Lessing, Gordimer has received less attention in China. The criticism of Gordimer has room for improvement.

First, the research objects are concentrated on Gordimer's novels. Her short stories are less attractive to Chinese scholars while they enjoy great popularity in literature field. There are few academic papers on short stories in recent years, most of which are not deep enough. Meanwhile, Chinese scholars prefer research on novels that have been translated into Chinese. Novels without Chinese edition, such as A World of Strangers or The Late Bourgeois World have almost never been criticized. In fact, these novels are valued greatly in foreign studies for their confrontation of "the limitations inherent in the position of the "colonial' writer" [41].

Secondly, the research field is not wide enough, and the quality of the research varies greatly. Recently, the number of academic paper on Gordimer that have been published in authoritative journals is less than that in first or middle stage. There are two reasons for this situation. On the one hand, the arguments based on classical methodology, such as post-colonialism or narratology are similar and lack of originality; On the other hand, Chinese research follows the steps of foreign achievement instead of innovation. It's easy for Chinese scholars to be limited by the research stereotype.

Lastly, the research system is not complete. In China, the journal articles and master dissertation about Gordimer are plentiful, but doctoral dissertation and monographs are limited. Therefore, there is still scope for academic research on Gordimer in China.

\section{Research Prospect of Nadine Gordimer in China}

Over the past 30 years, research on Gordimer in China has been gradually heated up, and achievements have been made, including outstanding academic paper. According to the current research status, more 
breakthroughs can be made in further studies.

In the first place, expand research fields and explore new perspectives. Gordimer's novels are "political, but not one-dimensional, undramatic or inartistic" [42]. Chinese scholars can firstly break the research stereotype and shift the focus from politics to the "spiritual level" [43], especially the cultural implication and philosophical intension in Gordimer's works. Although previous paper has already explored this field, there is still room to be improved. For example, how do Gordimer's works examine on the dialogue and communication between author and reader and how do they deal with the complex relationship between reality and fiction in a multicultural context; how do scholars extracts positive philosophical thoughts from Gordimer's ethical concerns in the ethical system. Then, Chinese scholars should pay greater attention to comparative research. Gordimer's writing has changed with the evolution of South African society. It's helpful to make a comparison between Gordimer's early and later works, to clarify the development of her ideology. Gordimer's writing style and theme had been influenced by literary figures such as Upton Sinclair and Virginia Woolf. The comparative research between such authors can reflect the similarities and difference of their creations, which is of great academic value. Finally, interdisciplinary research can provide a platform for communication among different subjects. Foreign scholars have already made interdisciplinary studies on Gordimer from the perspectives of linguistic, rhetoric, jurisprudence, etc., which is a good reference for Chinese scholars.

Secondly, improve the research system. In recent years, scholars such as Shen Yanyan, Lu Qingmei, Hu Zhongqing, Jiang Meng, etc., have published academic papers on Gordimer with their different perspectives. They have provided innovative ideas and opened a new prospect for the research. In the future, Chinese scholars need to expand research subjects and publish more doctoral dissertation and monograph. To make the research more systematic, scholars have to be highly familiar with Gordimer and her works, as well as the development of South African history.

Last, actively construct the critical discourse with Chinese characteristics. Chinese scholars can link the ideology reflected in Gordimer's works with Chinese social development to form a discourse system with Chinese characteristics. For instance, the contradiction between economic development and environmental protection in Get A Life can be combined with "the construction of ecological civilization" in China. Besides, Chinese theories and ideologies, such as Confucianism, Taoism, narrative ethics, or ethical literary criticism, can be applied to studies on Gordimer in China, which can promote multiculturalism.

From the first stage of research to the recent stage, Chinese research on Gordimer has made rapid progress. Though having the hysteresis quality compared with foreign studies, a broad space is left for Chinese scholars. Based on the current research status, it is hoped that the review above can make future studies more prosperous.

\section{REFERENCES}

[1] YANG Yuzhen. A Literature Review on the Research of Nadine Gordimer in China, Journal of Jishou University (Social Sciences Edition), Vol.31, No.2, 50-53, 2010.

[2] DONG Dingshan. A Justicial South African Female Writer, Du Shu, No.8, 140-144, 1987.

[3] HU Dejiang. Nadine Gordimer Has Won the Nobel Prize in Literature in 1991, Foreign Literature Studies, No.4, 143, 1991.

[4] HUANG Tianhai. A Mosaic of the Racial Society, Journal of Zhejiang University (Humanities and Social Sciences), Vol. 30, No.5, 153-157, 2000.

[5] ZHANG Zhongzai. Nadine Gordimer and A Sport of Nature, Foreign Literature, No.1, 73-77, 1993.

[6] REN Bing, Yang Gaitao. The Gained and Destroyed in the Struggle- - An Analysis of Nadine Gordimer's My Son's Story, Journal of Taiyuan Teachers College, No.3, 30-32, 1999.

[7] SHEN Yanyan. Review and Prospects of Nadine Gordimer Studies in China, Journal of Huzhou Teachers College, Vol. 29, No.6, 33-37, 2007.

[8] J. Newman, Nadine Gordimer, Routledge, UK, 1988.

[9] HU Zhongqing. The Inter-construction of the "Other" Image: A Postcolonial Approach to My Son's Story, The World Literature Criticism, No.1, 174-177, 2007.

[10] LU Qingmei. Nadine Gordimer's Postcolonial Status Reflected in My Son's Story, Xinjiang University, China, 2005.

[11] ZHU Qilin. The Diaspora and Cultural Identity in The Pickup, Journal of Chongqing University of Science and Technology (Social Sciences Edition), No.19, 117-119, 2010.

[12] J. F. URAIZEE. "Is There Nowhere Else Where We Can Meet?" The Post-Colonial Woman Writer and Political Fiction, Purdue University, USA, 1994.

[13] ZHOU Leshi. Nationalized Gender and Sexualized Nation-An Analysis of Nadine Gordimer's My Son's Story, Foreign Literature, No.4, 58-62, 2009.

[14] SHEN Yanyan. On the Bildungsroman of Rosa Burgher in Burgher's Daughter, Journal of Shaoguan University, Vol.28, No.2. pp. 21-24, 2007.

[15] C. L. PRIGAN. Redeeming History in the Story: Narrative Strategies in the Novels of Anna Seghers and Nadine Gordimer, The Ohio State University, USA, 1991.

[16] RUAN Hang. Leaving An Aesthetic Blank for Readers- The Narrative Strategy of My Son's Story, Journal of Sichuan College of Education, Vol.18, No.3, 23-24, 2002. 
[17] WANG Tao. Double Narrative Strategy-—A Study on the National Metaphor under Personal Narrative in My Son's Story, Journal of Xiangtan University (Philosophy and Social Sciences), No.4, 92-94, 2005.

[18] WANG Mei. Reality under the Drifting of Consciousness- the Narration Technique of None Accompany Me, Journal of Chongqing Technology and Business University (Social Sciences Edition), Vol.25, No.3, 131-134, 2008.

[19] WANG Mei. Narratives on Dialogues: Dialogues in the Third Person Narratives of Burger's Daughter, Foreign Language and Literature, Vol.26, No.2, 46-50, 2010.

[20] SHEN Yanyan. Decoding Cultural Pathology in Burger's Daughter, Contemporary Foreign Literature, Vol.30, No.3, 56-64, 2009.

[21] SHEN Yanyan. A Prophecy Novel of Transition- - An Analysis of Nadine Gordimer's July's People, Foreign Languages Research, Vol.120, No.2, 82-87, 2010.

[22] SHEN Yanyan. The Cultural Implication of Metaphor and Irony in Get A Life, Journal of Mudanjiang University, Vol.17, No.8, 15-16+32, 2008.

[23] WANG Xufeng. Liberation Politics and Post-Colonial Literature, Nankai University, China, 2009.

[24] LI Meiqin. The Black and White Miracle in the "Others' Land"- - Toni Morrison and Nadine Gordimer, Journal of Xi'an International Studies University, Vol.14, No.4, 73-75, 2019.

[25] SHEN Yanyan. Where is Youth- - An Interpretation of Coetzee's Youth and Gordimer's Burger's Daughter, Era Literature, No.2, 47-48, 2010.

[26] LU Qingmei. Nadine Gordimer: Transcending the Limits of Postcolonial Writing, Contemporary Foreign Literature, Vol.33, No.2, 20-29, 2012.

[27] LI Meiqin, Jiang Zhiqiang. On Political Metaphor of the Spatial Landscapes in Gordimer's July's People, Foreign Language and Literature Research, Vol.4, No.5, 32-39, 2018 .

[28] LIANG Benbin, Li Tianyun. The subversion and reconstruction of spatial narrative in None Accompany Me, Journal of Chongqing University of Education, Vol.27, No.5, 93-95+150.

[29] MU Xinyu. Conflict and Crisis: An Analysis of None to
Accompany Me from the Perspective of Spatial Criticism, Yanshan University, China, 2016.

[30] HU Zhongqing. Narration of Geographic Spaces in The Pickup, Journal of Taiyuan University (Social Science Edition), Vol.19, No.1, 71-76+88, 2018.

[31] PANG Hao'nong. South Africa's Pan-Ecosystem in Nadine Gordimer's July's People, Journal of Zhejiang Normal University (Social Sciences), Vol.41, No.5, 9-14.

[32] CAO Yawen. A Study of Nadine Gordimer's Ecofeminist Thoughts in The Pickup, Huaqiao University, China, 2019.

[33] HU Zhongqing. On the Ecological Aesthetics in Gordimer's Novel The Pickup, Journal of Yangtze University (Social Sciences), Vol.39, No.3, 17-22, 2016.

[34] YANG Li. Reading Get a Life from the Perspective of Ecocriticism, Huaqiao University, China, 2013.

[35] JIANG Meng. Get A Life: Crisis and Salvation in Post-apartheid Period, Journal of Chifeng University (Soc.Sci), Vol.40, No.11, 76-79, 2019.

[36] HU Zhongqing, Cai Shengqin. On the Theme of Alienation in Gordimer's Later Works, Hubei Social Sciences, No.1, 8-12, 2016.

[37] LIU Jie. The Significance of Alienation in Gordimer's Late Works, The World Literature Criticism, No.2, 173-178, 2018.

[38] HU Zhongqing. Three Ethical Relationships in Gordimer's Get A Life, Journal of Guizhou University (Social Sciences), Vol.34, No.4, 161-166, 2016.

[39] XU Tian. A Study on the Narrative Ethics of Nadine Gordimer's Novels, Central China Normal University, China, 2019.

[40] HU Zhongqing. A study on the Archetypal Image of Biblical Myth in Gordimer's Novels, Journal of Yangtze University (Social Sciences), Vol.42, No.3, 8-12, 2019.

[41] J. H. Cooke. The Novels of Nadine Gordimer, Northwestern University, USA, 1976.

[42] R. C. Otero. The Novels of Nadine Gordimer, The University of New Mexico, USA, 1983.

[43] J. M. Coetzee. Inner Workings: Literary Essays, 2000-2005, Harvill Secker, UK, 2007. 